\title{
Families of Children with Chronic Illness and the Relational Family Model
}

\begin{abstract}
Families of children with chronic illness experience persistent stress. Facing the diagnosis and learning how to cope with it is a stressful experience not only for the child but also for the parents and for the whole family. The illness, with its unpredictability and treatment, disturbs their daily routine and threatens the whole family system. Parental involvement in the child's disease management and their emotional support are crucial for effective coping and adaptation to the child's chronic illness. The aim of this article is to present the importance of the parental role in these families through theoretical findings of the relational family model.
\end{abstract}

Keywords

Chronic illness, parents, children, relational family therapy, affect regulation.

\section{Chronic illness in childhood}

Chronic illness in childhood includes any medically and scientifically diagnosed disease or condition that occurs in children up to 18 years of age. The chronic disease must be present for more than three months and incurable. Pediatric chronic illness is increasingly affecting more and more children, adolescents and families. The prevalence of childhood chronic illness varies from relatively common pediatric asthma and diabetes to rarer 
conditions such as cystic fibrosis. ${ }^{1}$ Some chronic diseases have demanding treatment regimens that require considerable effort, time and emotional strength. Other diseases, such as diabetes, nowadays have more flexible treatment management because of better technology (e.g. insulin pumps, continuous glucose monitoring systems). However, research shows that the problem of acute and chronic complications due to a child's developmental and psychological factors still remains. ${ }^{2}$ Pediatric chronic illness can affect children's psychological adjustment and their level of functioning. ${ }^{3}$ While many children may cope well with the demands of physical illness, children and adolescents with chronic illness are at higher risk of developing psychological problems compared to their peers with no known chronic illness. Children react in many different ways to chronic illness and some important risk factors are definitely pain, cognitive difficulties, visibility and appearance-related factors as well as the impact that any of these might have on daily life. Children acquire information and explanations about their bodies and how they work consistently with their developmental phase. As they develop their knowledge of the body and organs, they will understand that illness may be due to an organ not working inside and they will gradually understand causation of illness, including germs, environmental and psychological factors. However, the child's cognitive skills to understand illness are not enough for him not to feel anxious about what is happening to him. Adaptation to illness is conceptualized as a model of risk and resiliency. Helping children must include a collaborative relationship with knowledge and information about procedures and illness, support and skills to meet existing challenges, thus developing their effective coping style. ${ }^{4}$

${ }^{1}$ L. Mokkink, J. H. van der Lee, M. A. Grootenhuis, M. Offringa H. S. Heymans, Defining chronic diseases and health conditions in childhood (0-18 years of age): national consensus in the Netherlands, »European Journal of Pediatrics« (2008) Nr. 12, p. 1441-1447.

${ }^{2} \mathrm{~J}$. Unger, Uncovering undetected hypoglycemic events, "Diabetes, metabolic syndrome and obesity: targets and therapy« (2012) Nr. 5, pp. 57-74.

${ }^{3}$ F. Snoek, C. Skinner, Psychology in Diabetes Care, Second edition ed. West Sussex 2005, John Wiley \& Sons, p. 32.

${ }^{4}$ M. Edwards, P. Titman, Promoting psychological well-being in children with acute and chronic illness, London 2010: Jessica Kingsley Publishers, pp. 36-54. 


\section{Chronic illness and family system}

For parents, facing their child's diagnosis of chronic illness is a particularly traumatic event. Levels of anxiety, anger, shock and uncertainty are normal in the initial phase of illness. ${ }^{5}$ After diagnosis the requirement of self-control and disease management carried out by healthcare specialists is shifted to parents, and consequently to the whole family. Chronic illness causes stress in the child and his family. The child's chronic illness becomes, as though, a new family member.

There are two elements of family dynamics that are important in families with chronic illness: family style and family life cycle. Family style is defined as the degree of centripetal and centrifugal qualities in the family and both of these are contributors to the impairment or health of family relationships. Healthy adjustment over time is reached through a flexible balance between centrifugal and centripetal qualities. Family is also viewed as developing in progressive stages (e.g. parenting the first child; living with an adolescent; launching the children), where instability provokes a shift to a new state in which the family develops new tasks and attitudes. The ability to recognize and differentiate between different periods of greater or minor psychosocial demands can lead to improved care for the child's chronic illness. ${ }^{6}$

Chronic illness is a very psychologically demanding stressor for families. It changes the roles of family members and disrupts the hierarchy, influences family communication, interpersonal relationships and finances. However, family can also influence the physiology as well as the daily management of chronic illnesses. Family life can be focused exclusively on the child's illness and needs. Research shows that families with young children have a higher risk that their child would become apprehensive and overly dependent on his/her parents, whereas parents would become highly concerned and emotionally occupied. ${ }^{7}$ High levels of family stress and enmeshed roles can place excessive attention

${ }^{5}$ R. Cvetek, Bolečina preteklosti: travma, medosebni odnosi, družina, terapija, Celje 2009: Celjska Mohorjeva družba, Društvo Mohorjeva družba, p. 14.

${ }^{6}$ L. Sperry, Behavioral health: integrating individual and family interventions in the treatment of medical conditions, New York 2013: Routledge, p. 11-17.

7 L. Mullins, C. Wolfe-Christensen, A. Hoff Pai, M. Carpentier, S. Gillaspy, J. Cheek, M. Page. The relationship of parental overprotection, perceived child vulnerability, and parenting stress to uncertainty in youth with chronic illness. ") Journal of Pediatric Psychology « (2007) Nr. 8, pp. 973-982. 
on physical symptoms and unintentionally extend their duration. ${ }^{8}$ Family criticism, hostility and nagging can undermine the patient's efforts to adhere to medical recommendations and make lifestyle changes. With the onset of the child's chronic illness, pre-existing problems and difficulties in the marriage subsystem are often exacerbated. Family conflicts and enmeshed relationships defined by unclear roles, rules and demolished family hierarchy are associated with poorer disease outcomes, whereas family cohesion is associated with better disease management. ${ }^{9}$ How well each family adapts to chronic illness can influence the course of the illness as well as the relationship between patients and their clinicians. ${ }^{10}$

\section{Parental role and experience of psychosocial impact of child's chronic illness}

Parents of children with chronic illness are the main source of emotional support for the child and an important link between their child and the health care team. An active attitude of the parents in managing their child's illness, and their adjustment to the new way of life predict better child's self-control later in adulthood. Through the process of diagnosis and coping with the disease, parents gain additional expertise and knowledge about their child's illness. Parents become responsible for disease management, which may include regular measurements, medication management, healthy and balanced diet or physical activity (depending on the child's illness and age). All these skills and regimens are needed to avoid high fluctuations in the course of the disease, which may influence the child's development, and to enable a better quality of life. Parents must cope not only with illness management but also with their fears, sorrow, grief, anger, sadness and despair which are associated with the loss of a healthy

${ }^{8}$ M. Shorer, R. David, M. Schoenberg-Taz, I. Levavi-Lavi, M. Phillip, J. Meyerovitch. Role of parenting style in achieving metabolic control in adolescents with type 1 diabetes, "Diabetes Care« (2011) Nr. 34, pp. 1735-1737.

9 B. Anderson, L. Vangsness, A. Connell, D. Butler, A. Goebel-Fabbri, L. Laffel, Family conflict, adherence, and glycaemic control in youth with short duration Type 1 diabetes, "Diabetic Medicine« (2002) Nr. 19, pp. 635-642.

${ }^{10}$ D. Drotar, Psychological interventions in childhood chronic illness, Washington DC 2006: American psychological association, p. 18. 
child and, consequently, the previous way of life, and the constant threat of illness and its later complications. ${ }^{11}$

Psychological distress is greater in parents of children with chronic illness than in parents of children without chronic disease. Parental experience of psychological distress is another factor that interferes with the process of adjustment to the new way of family life with chronic illness. Constant involvement in disease management is often associated with parents experiencing anxiety and stress, especially parents of younger children. ${ }^{12}$ Research shows that parental experience of stress, anxiety and depression is greater in mothers. Some studies show that mothers experience their child's diagnosis of chronic illness as traumatic stress. Post-traumatic stress symptoms are a significant and distressing sequel to experiencing a life-threatening illness. ${ }^{13}$ Mothers experience greater parental stress, feelings of depression and burnout, whereas fathers are generally less functionally involved in the process of disease management. This is also associated with poor disease outcomes. ${ }^{14}$

However, parents are not only important as a child's health experts and educators. They have an important role in regulating their child's and their own emotions created by the illness, the regimen and its management. The role of parents and their way of coping with the child's illness and its management is central. Therefore, it is important for parents to recognize and identify emotions, and the debilitating effect that these might have on their family.

\section{Relational family therapy paradigm and families with chronically ill children}

Relational Family Therapy (RFT) is a psycho-biological model based on the assumption that patterns (of early relationships with parents, bodily, emotional

${ }^{11}$ M. Edwards, P. Titman, Promoting psychological well-being in children with acute and chronic illness, London 2010: Jessica Kingsley Publishers, pp. 60-66.

12 D. Drotar, Psychological interventions in childhood chronic illness, Washington DC 2006: American psychological association, pp. 36-40.

13 A. Spirito, A. Kazak, Effective and emerging treatments in pediatric psychology, Oxford 2006: Oxford University press, p. 44.

${ }^{14}$ M. Shorer, R. David, M. Schoenberg-Taz, I. Levavi-Lavi, M. Phillip, J. Meyerovitch, Role of parenting style in achieving metabolic control in adolescents with type 1 diabetes, "Diabetes Care« (2011) Nr. 34, pp. 1735-1737. 
and behavioral sensations) repeat through the life cycle on the systemic, interpersonal and intrapsychic level. ${ }^{15}$ RFT focuses on the unique context, the needs, the resources of individual family members and the system as a whole. In light of this perspective, the common elements for assessment are client factors (personality dynamics and level of functioning; personal strengths and resources), family structure and interaction patterns (couple and parental subsystem dynamics and functioning; family resources and strengths), cultural factors and intergenerational patterns as well as narrative and social discourses. ${ }^{16}$

The premise of RFT is that maintenance of human relatedness is the fundamental motivational element and not just the maturational process into which humans are inevitably engaged. RFT focuses on powerful components of the individual, couple and the whole family's system. Since birth, children are entirely connected with and physically dependent upon their mother and, from the $18^{\text {th }}$ month on, with their father as well. Father and mother are an essential source of attachment and feeling of safety for the child. Early relationships, experiences and emotions that are stored in somatic memory, shape the way in which children, and later adults, unconsciously build intrapsychic and interpersonal relationships, as well as their way of perceiving, thinking, feeling and experiencing. ${ }^{17}$ Children's experiences of early relationships with parents, body, emotionally and behaviorally sensations are, according to the family relational model, continuously repeating through the life cycle on the systemic, interpersonal and intrapsychic level. ${ }^{18}$

Through the interpersonal and systemic matrix of relationships family members learn and develop skills for functional communication and emotion regulation. A family that sustains clear boundaries between the couple's, parental and child's subsystem, and where rules and member's roles are maintained in constant balance, is an emotionally secure space. Alternatively, in families with demolished boundaries, unclear or overly strict rules and roles, members get

15 C. Gostečnik, Inovativna relacijska družinska terapija, Ljubljana 2011: Brat Frančišek, Teološka fakulteta \& Frančiškanski družinski inštitut, pp. 38-43.

${ }^{16} \mathrm{~J}$. Bitter, Theory and practice of family therapy and counseling, Belmont, CA: Brooks/ Cole.

17 D. Siegel, M. Hartzell, Parenting from the inside out: how a deeper self-understanding can help you raise children who thrive, New York 2003 Jeremy P. Tarcher/Penguin, pp. 17-25.

18 C. Gostečnik, Inovativna relacijska družinska terapija, Ljubljana 2011: Brat Frančišek, Teološka fakulteta \& Frančiškanski družinski inštitut, pp. 9-24. 
feelings of redundancy. Such a family system reaches its equilibrium in a way that transfers the tensions and pressures on the children, who become the holders of unresolved family conflicts. A child's poor behavior could be understood as his or her way of seeking salvation from these deep emotional complications and an attempt to find someone who will save and accept them. ${ }^{19}$

Parents of children with chronic illness find themselves in an entirely new role and must newly regulate their child's physical (medication, food, rest) and mental states (level of stress, emotions), and inform the social environment (relatives, friends, school, kindergarten, colleagues etc.), which may lead to feelings of unacceptability, misunderstandings, guilt, anger and stress. ${ }^{20}$ RFT may help the family adjust to the new situation created by their child's chronic illness, facilitate acceptance around loss of health, explore the new meaning of the illness, as well as identify and regulate any painful feelings and emotions. ${ }^{21}$ Therapists assist parents in coping with the diagnosis and help them regain self-efficacy and the ability to cope well with the symptoms of the illness as well as other family and life stressors. This will also empower parents to maintain a responsible and productive collaboration between their child, other family members and the health care team, and to sustain open family communication about the consequences and emotions brought up by the disease. ${ }^{22}$

RFT traces the mechanism of affect regulation, which has an important role in balancing parental intrapsychic experiences as well as experiences in parentchild relationship and coping with child's anxiety, fear and other emotions. The process of affect regulation enables the development of a healthy identity, as well as the further development of identity. The situation created by a child's chronic illness may cause feelings of unacceptability, misunderstandings, guilt, anger and sadness. The affect regulation process helps parents to regulate their child's distress influenced by chronic illness, in a way that they first identify difficult

19 C. Gostecnik, T. Repic, R. Cvetek, Redemptive experience in relational family therapy: a Christian perspective, »Journal Religion and health« (2008) Nr. 47, pp. 386-397.

${ }^{20}$ K. Atkin, W. Ahmad, Family care-giving and chronic illness: how parents cope with a child with a sickle cell disorder or thalassaemia, »Health and Social Care in the Community« (2000) Nr. 1, pp. 57-69.

21 T. Pate, Relacijska družinska terapija in dinamika otrokove kronične bolezni v družini, in: B. Simonič (ed.), Relacijska družinska terapija $v$ teoriji in praksi, Ljubljana 2015: Teološka fakulteta Univerze v Ljubljani \& Frančiškanski družinski inštitut, pp. 135-149.

22 C. Gostečnik, Sistemske teorije in praksa, Ljubljana 2010: Založba Brat Frančišek \& Frančiškanski družinski inštitut, pp. 152-158. 
feelings and emotions and transform them into something that is manageable and acceptable for the child. Therefore, parents are not important only as lay healthcare professionals for their child with chronic illness, but they are also important regulators for all difficult emotions, such as fear, sadness, anxiety, anger, shame and guilt. The relational family model offers an interpretation of emotion regulation, its meaning and role in a child's chronic illness and helps the family adjust to the new situation.

\section{Bibliography}

Anderson B., Vangsness L., Connell A., Butler D., Goebel-Fabbri A., Laffel L., Family conflict, adherence, and glycaemic control in youth with short duration Type 1 diabetes. "Diabetic Medicine" (2002) Nr. 19, pp. 635-642.

Atkin K., Ahmad W., Family care-giving and chronic illness: how parents cope with a child with a sickle cell disorder or thalassaemia, "Health and Social Care in the Community" (2000) Nr. 1, pp. 57-69.

Bitter J., Theory and practice of family therapy and counseling, Belmont, CA: Brooks/Cole.

Cvetek R., Bolečina preteklosti: travma, medosebni odnosi, družina, terapija, Celje 2009: Celjska Mohorjeva družba, Društvo Mohorjeva družba.

Drotar D., Psychological interventions in childhood chronic illness, Washington DC 2006: American psychological association.

Edwards M., Titman P., Promoting psychological well-being in children with acute and chronic illness, London 2010: Jessica Kingsley Publishers.

Gostečnik C., Inovativna relacijska družinska terapija, Ljubljana 2011: Brat Frančišek, Teološka fakulteta \& Frančiškanski družinski inštitut.

Gostecnik C., Repic T., Cvetek R., Redemptive experience in relational family therapy: a Christian perspective, "Journal of Religion and Health" (2008) Nr. 47, pp. 386-397.

Gostečnik C., Sistemske teorije in praksa, Ljubljana 2010: Založba Brat Frančišek \& Frančiškanski družinski inštitut.

Mokkink L., Lee J. H. van der, Grootenhuis M.A., Offringa M., Heymans H.S., Defining chronic diseases and health conditions in childhood (0-18 years of age): national consensus in the Netherlands, "European Journal of Pediatrics" (2008) Nr. 12, p. 1441-1447.

Mullins L., Wolfe-Christensen C., Hoff Pai A., Carpentier M., Gillaspy S., Cheek J., Page M., The relationship of parental overprotection, perceived child vulnerability, and parenting stress to uncertainty in youth with chronic illness, "Journal of Pediatric Psychology" (2007) Nr. 8, pp. 973-982.

Pate T., Relacijska družinska terapija in diamika otrokove kronične bolezni v Drwini, in: B. Simonič (ed.), Relacijska družinska terapija v teoriji in praksi, Ljubljana 2015: Teološka fakulteta Univerze v Ljubljani \& Frančiškanski družinski inštitut, pp. 135-149. 
Shorer M., David R., Schoenberg-Taz M., Levavi-Lavi I., Phillip M., Meyerovitch J., Role of parenting style in achieving metabolic control in adolescents with type 1 diabetes, "Diabetes Care" (2011) Nr. 34, pp. 1735-1737.

Siegel D., Hartzell M., Parenting from the inside out: how a deeper self-understanding can help you raise children who thrive, New York 2003 Jeremy P. Tarcher/Penguin, pp. 17-25.

Snoek F., Skinner C., Psychology in Diabetes Care, Second edition ed. West Sussex 2005, John Wiley \& Sons.

Sperry L., Behavioral health: integrating individual and family interventions in the treatment of medical conditions, New York 2013: Routledge.

Spirito A., Kazak A., Effective and emerging treatments in pediatric psychology, Oxford 2006: Oxford University press.

Unger J., Uncovering undetected hypoglycemic events, "Diabetes, metabolic syndrome and obesity: targets and therapy" (2012) Nr. 5, pp. 57-74. 